\title{
Analysis of opioid-mediated analgesia in Phase III studies of methylnaltrexone for opioid-induced constipation in patients with chronic noncancer pain [Corrigendum]
}

\author{
Webster LR, Brenner DM, Barrett AC, Paterson C, \\ Bortey E, Forbes WP. J Pain Res. 2015;8:771-780.
}

Page 772 , left column, line 34 , the text “ $(\geq 45 \mathrm{mg} / \mathrm{kg})$ )" should read " $(\geq 0.45 \mathrm{mg} / \mathrm{kg})$ ".

Page 773, left column, Pain intensity, line 4, the text "baseline (BL), day 1, weeks 2 and 4" should read "baseline (BL), weeks 2 and 4".

Page 779, left column, line 16, the text "(ie, 6 weeks)" should read "(ie, 4 weeks)".

The Journal of Pain Research is an international, peer reviewed, open access, online journal that welcomes laboratory and clinical findings in the fields of pain research and the prevention and management of pain. Original research, reviews, symposium reports, hypothesis formation and commentaries are all considered for publication.
The manuscript management system is completely online and includes a very quick and fair peer-review system, which is all easy to use. Visit http://www.dovepress.com/testimonials.php to read real quotes from published authors. 